\title{
SOSIALISASI EKOLOGI TEOLOGI BAGI JEMAAT GKSI IMMANUEL BAGI PENGHIJAUAN DI KECEMATAN KUALA BEHE
}

\author{
Damaris Resfina ${ }^{1}$ \\ Sekolah Tinggi Teologi Injili Arastamar (SETIA) Jakarta \\ damarisresfina@gmail.com
}

Abstrak

\begin{abstract}
Diterima:
30-08-2020

Direvisi:

05-09-2020

Diterbitkan:

30-09-2020

Kata Kunci:

Ekoteologi,

Misiologi, Etika

Lingkungan

Keywords:

Ecoteology,

Missiology,

Environmental

Ethics

Sosialisasi Ekologi tentang Penghijauan merupakan salah satu kegiatan penting yang harus dilaksanakan secara konseptual dalam menangani krisis lingkungan. Masyarakat di Kuala behe dominan bekerja sebagai pertambangan emas tanpa izin, dengan adanya pekerjaan seperti ini tanpa memikirkan sebuah solusi maka penebangan hutan sembarangan akan berkelanjutan sehingga menimbulkan efek negatif bagi alam dan masyarakat. Pada dasarnya masyarakat di Kuala Behe mempunyai hukum adat tertulis yang melarang penebangan pohon sembarang akan tetapi kurang aktif di tegakkan karna pertambangan emas merupakan peluang bagi masyarakat untuk memenuhi kebutuhan hidup hari demi hari. Dengan demikian Kegiatan sosialisasi penghijauan yang dilakukan jemaat GKSI Immanuel Kuala Behe bertujuan antara lain; untuk menambah nilai ekologi, menambah nilai estetika, serta alasan untuk mendukung program pemerintahan selain itu tulisan ini membahas tentang kajian teologi kontekstual-ekologis. Pemahaman masalah lingkungan hidup dan penanganannya perlu diletakkan di atas suatu pondasi etika dan moral untuk mendukung segala upaya yang sudah dilakukan dan di bina selama ini meski ternyata belum mampu mengatasi kerusakan lingkungan hidup. Sosialisasi penghijauan yang dilakukan Jemaat GKSI IMMANUEL Kuala Behe merupakan tindakan untuk menyadarkan bahwa masalah lingkungan hidup tidak terlepas dari tanggung jawab manusia yang beriman dan merupakan Amanat Agung Tuhan untuk memelihara dan melindungi alam dari segala macam kerusakan yang berakibat mengancam hidup.

Abstract

The important things to do in Ecological theology is socialization to many people. The people in Kuala Behe predominantly work as unlicensed gold mining, with work like this without thinking of a solution the indiscriminate deforestation will be sustainable so as to have negative effects on nature and society. Basically, the people in Kuala Behe have written customary laws that prohibit the felling of trees carelessly but are not actively enforced because gold mining is an opportunity for the community to fulfill their daily needs. Thus, the greening socialization activities carried out by the GKSI IMMANUEL Kuala Behe congregation were aimed at; to add ecological value, add aesthetic value, as well as reasons for supporting government programs besides this paper discusses the study of contextual-ecological theology. Understanding of environmental problems and their handling need to be placed on an ethical and moral foundation to support all efforts that have been done and developed so far although it has not been able to overcome environmental damage. Greening socialization conducted by the GKSI IMMANUEL Kuala Behe congregation is an act to realize that environmental problems are inseparable from the responsibility of faithful humans and are God great mandate to preserve and protect nature from all kinds of damage that results in life threatening.
\end{abstract}

\section{PENDAHULUAN}

Ekoteologi merupakan sebuah konsep teologi yang mendekatkan kembali pemahaman Teologis Kristen, dengan jejaring lingkungan alam. Ekoteologi hadir sebagai sebuah tanggapan terhadap krisis lingkungan yang terjadi. Hubungan manusia dan alam dalam ekoteologi dimaknai sebagai rekan sekerja dan relasionsl dalam mewujudkan nilainilai kerajaan Allah. Konsep Ekoteologi ini berangkat dari asumsi bahwa manusia sebagai pusat ciptaan ditugaskan Allah untuk merawat dan memelihara keutuhan ciptaan (lih. Kej.1:28-30). Manusia mendapatkan tanggung jawab baru dalam membangun relasinya dengan alam dan menjaga keberlangsungan alam. Dengan demikian Nampak disini bagaimana misi Allah yang diberikan kepada manusia.

${ }^{1}$ Mahasiswa Prodi Teologi, Sekolah Tinggi Teologi Injili Arastamar (SETIA) Jakarta 
Misi selalu berasal dari Allah, gereja melalukan semua yang Allah perintahkan. Misi adalah suatu kegiatan yang mengutus seorang atau kelompok ke suatu tempat atau daerah tertentu, untuk melaksanakan program atau kegiatan dalam jangka waktu tertentu. Dalam konteks kaitan antara konten misi dan ekoteologi khususnya ke daerah-daerah tertentu, diperlukan strategi, metode dan pendekatan-pendekatan tertentu. Oleh sebab itu Misi dan pelayanan sosial adalah dua hal yang saling berkaitan dalam mendukung Amanat Agung Tuhan Yesus. Etika Lingkungan mefokuskan diri pada bagaiman perilaku manusia yang seharusnya terhadap lingkungan. Etika lingkungan sekaligus merupakan kritik atas etika yang selama ini dianut manusia yang membatasi diri pada komunitas sosial. Dalan dimensi ekoteologi melihat bahwa krisis lingkungan yang sekarang ada tidak lepas dari sikap dan perspektif manusia terhadap alam. Manusia modern memandang alam sebagai obyek yang harus dieksplotasi demi tercukupinya kebutuhan tanpa memikirkan dampaknya.

Masalah kerusakan alam atau lingkungan hidup dan akibat-akibat yang di timbulkan bukanlah suatu hal yang asing lagi di telinga setiap orang. Dengan sistematis setiap orang dapat menunjuk dan mengetahui apa saja jenis kerusakan lingkungan hidup dan akibat yang ditimbulkannya. Misalnya; ekploitasi alam dan penebangan hutan yang terlalu berlebihan dapat menyebabkan bencana banjir, tanah longsor dan kelangkaan air bersih. Yang menjadi masalah adalah bahwa pengetahuan yang sama atas pengenalan kerusakan lingkungan hidup dan akibat yang di timbulkan tersebut belum terjadi dalam hal pemeliharaan dan perawatan lingkungan hidup, seolah-olah perawatan dan pelestarian bukan tanggung jawab manusia.

Pengetahuan dan informasi kerusakan lingkungan hidup, bencana alam saja tidak cukup untuk mengatasi masalah kerusakan lingkungan hidup. Dalam menghadapi masalah kerusakan lingkungan hidup dewasa ini, kekuatan ilmu pengetahuan dan teknologi, bahkan juga kekuatan ekonomi, tidak lagi memadai untuk memampukan manusia membendung kerusakan lingkungan. Orang percaya harus kembali memahami panggilannya ditengah dunia, yaitu hati nurani, nilai-nilai kemanusiaan dan Penciptanya.

Manusia merupakan satu-satunya makhluk ciptaan Tuhan yang berakal budi. Alam merupakan lingkungan kehidupan atau segala sesuatu yang ada di langit dan di bumi seperti tumbuh-tumbuhan dan binatang. Manusia dan alam mempunyai hubungan yang saling tergantung dan saling membutuhkan. Pemazmur mengatakan bahwa Allahlah pemilik alam semesta ini. "Tuhanlah yang empunya bumi serta segala isinya dan dunia serta yang diam di dalamnya" (Mazmur 24:1). Tuhan telah menciptakan segala sesuatu dari ketiadaan, jika manusia ingin menciptakan sesuatu, harus menggunakan apa yang telah di ciptakan oleh Allah termasuk alam sebagai ciptaan Allah. Alkitab berbicara tentang ciptaan yang baru dan bumi yang baru (Wah. 21:1), di mana bumi yang baru tersebut adalah bebas dari polusi (pencemaran), destruksi (pengerusakan). Manusia di tugasi oleh Allah dalam rangka menggalang keharmonisan manusia dan alam. Menurut Kejadian 1:28, ciptaan terakhir yakni manusia dan mendapatkan mandat untuk bertanggung jawab atas seluruh ciptaan.

Tetapi seiring berjalannya waktu, alam berubah wujud dari tampilan sebelumnya. Pengembangan aspek kehidupan, tidak terlepas dari kemajuan pola pikir manusia yang di titikberatkan kepada keadaan sekarang, usaha mempermudah kehidupan manusia karena kebutuhan hidup. Penyebab dari lingkungan hidup yang kian menjadi rusak adalah mungkin dikarenakan cara pandang dan sikap manusia yang telah salah terhadap alam. Karena memang benar pemahaman dan cara pandang orang terkait lingkungan hidup akan mempengaruhi sikap mereka dan cara mereka akan memperlakukan alam. Banyak yang berpandangan bahwa alam dapat dilihat sebagai objek, alat, dan sarana untuk memenuhi kebutuhan dan kepentingan manusia. Adanya pemikiran seperti itu akan memicu munculnya sikap yang tidak bersahabat dengan alam, dan tidak menghargai adanya lingkungan hidup untuk kepentingan banyak orang.

Krisis lingkungan hidup yang di alami manusia pada masa sekarang merupakan akibat dari kurang pedulinya manusia terhadap pengelolaan lingkungan hidup mereka sendiri, artinya manusia umumnya melakukan pengelolaan sumber-sumber alam tidak peduli pada peran etika. Dengan kata lain, krisis lingkungan hidup yang dialami manusia berakar pada krisis etika (moral). Manusia kurang peduli pada norma-norma kehidupan atau lebih peduli pada kepentingan diri sendiri. Secara teologis dapat dikatakan bahwa manusia dan alam adalah ciptaan, properti dan bait Allah, semuanya itu berada dalam suatu hubungan perjanjian dengan Allah. Barangsiapa yang merusak alam, maka ia merusak hubungan perjanjian itu. Di samping itu, segala kegiatan pengerusakan alam akan mendatangkan kerusakan pada hidup umat manusia. Alam merupakan pemberian Allah 
kepada manusia untuk memelihara dan dipergunakan (Kejadian 1). Oleh karena itu, etika lingkungan tiak berpusat pada manusia atau alam, melainkan berpusat kepada Allah.

\section{METODE PELAKSANAAN}

Prosedur yang dilakukan dalam kegiatan pengabdian ini terbagi menjadi 3 sesi yang dilakukan selama 1 minggu. Sesi pertama berupa penyuluhan kepada jemaat GKSI IMMANUEL betapa pentingnya dalam memperhatikan alam sekitar, kemudian sesi kedua pencarian bibit pohon unggul secara bersama-sama di hutan, dan Sesi Ketiga penanaman pohon dari polibeg ke tanah bersama jemaat GKSI IMMANUE Kuala Behe .

\subsection{Kegiatan Sesi 1}

Pada sesi pertama ini, dilakukan permintaan izin kepada ibu gembala dan kepada kepala desa untuk menyetujui program ini dilakukan dan pemilihan lokasi lahan untuk penanam pohon. kemudian jemaat diberikan pembekalan ilmu tentang sosialisasi Ekologi Teologi bagi penghijaun di Kecamatan Kuala Behe untuk meningkatkan nilai Ekologi dan menambah nilai estetika. Selanjutnya berbicara mengenai jadwal dari kelanjutan program ini. Dalam sesi ini penjelasan mengenai Sosialisasi Ekologi Teologi dalam rangka penghijauan akan di jelaskan oleh Damaris Resfina, dan kegiatan ini dilakukan pada tangga 19 Juli 2020, pukul 13.00-15.00 WIB.

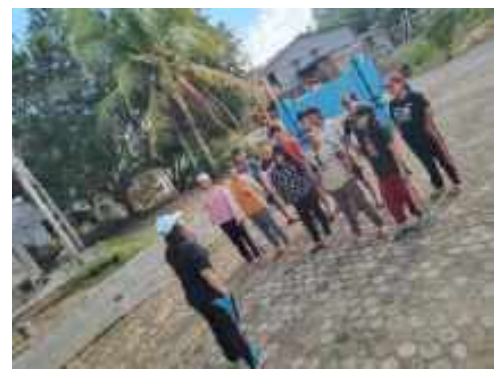

\subsection{Kegiatan Sesi 2}

Pada sesi kedua ini, jemaat akan dilibatkan dalam pencarian bibit pohon yang akan di tanam ke dalam polibeg. Kegiatan ini dilakukan pada tanggal 21 Juli 2020, pukul 15.0017.00 WIB dan di dampingi oleh Damaris Resfina sebagi pemandu dalam program sosialisasi penghijaun ini. Alat-alat yang digunakan polibeg, canggkul dan parang. Kepala desa memberikan sumbangsih berupa polibeg sebagai dasar menyetujui dan berperan dalam menjalankan program ini .
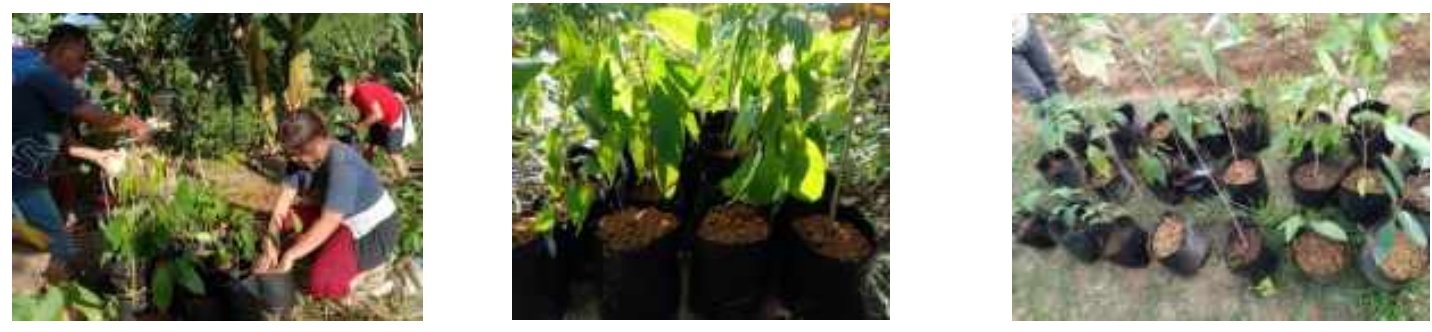

\section{3 kegiatan sesi 3}

Pada sesi ketiga ini, jemaat akan melakukan kegiatan penanaman pohon di lahan yang sudah ditentukan. Kegiatan ini dilakukan pada tangga 26 Juli 2020, pukul 15.00-17.00 WIB, di tempat lokasi pertanian milik masyarakat.

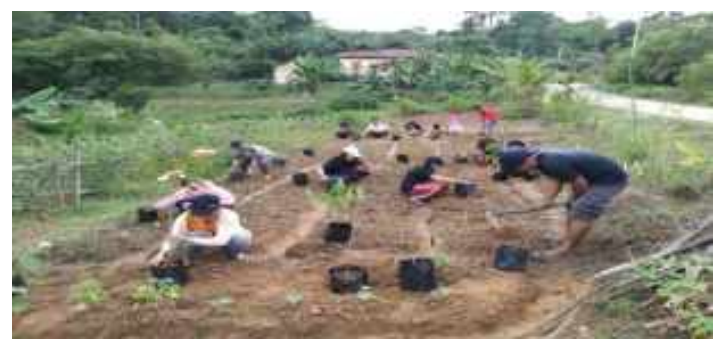




\section{HASIL DAN PEMBAHASAN}

Program pengabdian kepada masyarakat yang telah dirancang sedemikan rupa telah dilaksanakan sesuai dengan yang telah ditargetkan baik dari segi waktu maupun metode pelaksanaannya. Program ini dilakukan dari latar belakang melihat hutan di kalimantan sudah mulai rusak dan terjadinya bajir di beberapa wilayah. Berikut adalah gambar yang berhasil diambil;

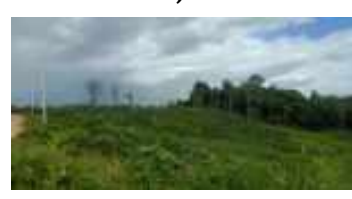

Gambar 1

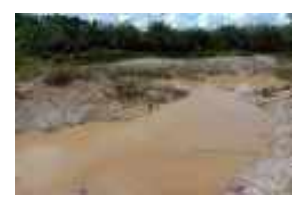

Gambar 2

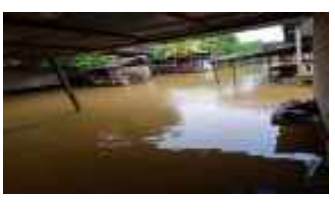

gambar 3

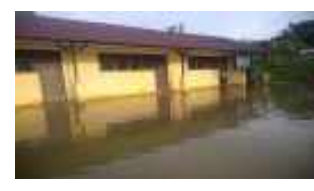

Gambar 4

Gambar 1 adalah gambar yang memperlihatkan kondisi hutan yang mulai gundul, dimana semua pohon sudah ditebang. Gambar 2 adalah gambar yang memperlihatkan hutan yang sudah di rusak oleh sebab pencarian tambang emas atau di sebut dengan istilah "DOMPENG". Gambar ke 3 adalah gambar yang memperlihatkan tempat tinggal masyarakat yang sudah terkana banjir dan Gambar ke 4 adalah gambar yang memperlihatkan kondisi sekolah yang sudah tergenang oleh banjir.

Dalam ekologi, di yakini bahwa sistem alam (ekosistem) dan sistem sosial saling berhubungan. Manusia berada dalam sistem sosial (yang di dalamnya mencakup nilai, cara berpikir, paradigma, pengetahuan, ideologi dan lain sebagainya) dan juga berada dalam ekosistem (yang terdiri dari air, tanah, udara, flora, fauna, alam dan lain sebagainya). Kedua sistem ini saling berhubungan dan saling mempengaruhi. Manusia memegang peranan yang sangat menentukan bagi kelestarian atau keberlangsungan kehidupan disekitarnya.

Menurut oleh Sudharto P. Hadi menggambarkan bahwa hubungan manusia dengan alam dibedakan menjadi tiga tahap yaitu sebagai berikut;

a. Tahap satu : manusia tunduk kepada alam. Pada tahap ini manusia berhubungan langsung dengan alam dalam rangka memanfaatkan sumber dari alam (ini terjadi pada jaman hunting and gathering). Skemanya adalah sebagai berikut:

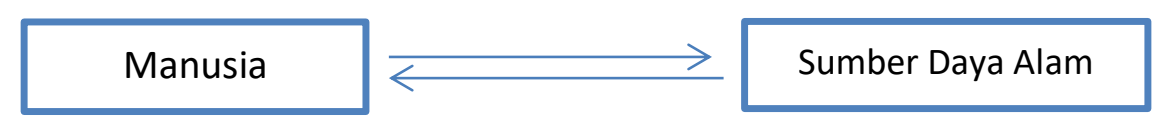

b. Tahap kedua : manusia menguasai alam. Dalam tahap ini manusia mulai menggunakan tehnologi untuk meningkatkan penguasaanya terhadap alam. Skemanya adalah sebagai berikut:

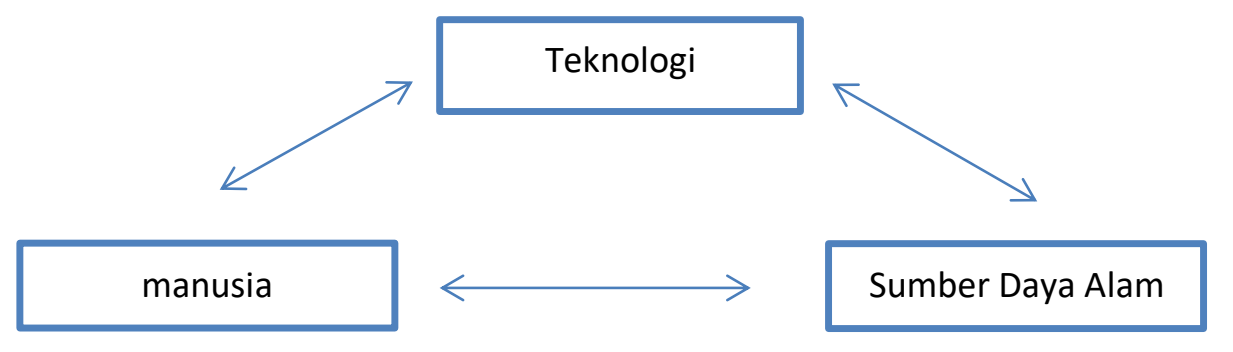

c. Tahap ketiga : tahap dimana manusia mulai mengorganisasikan alam melalui tehnologi demi menghisap sumber daya sebanyak-banyaknya. Skemanya adalah sebagai berikut;

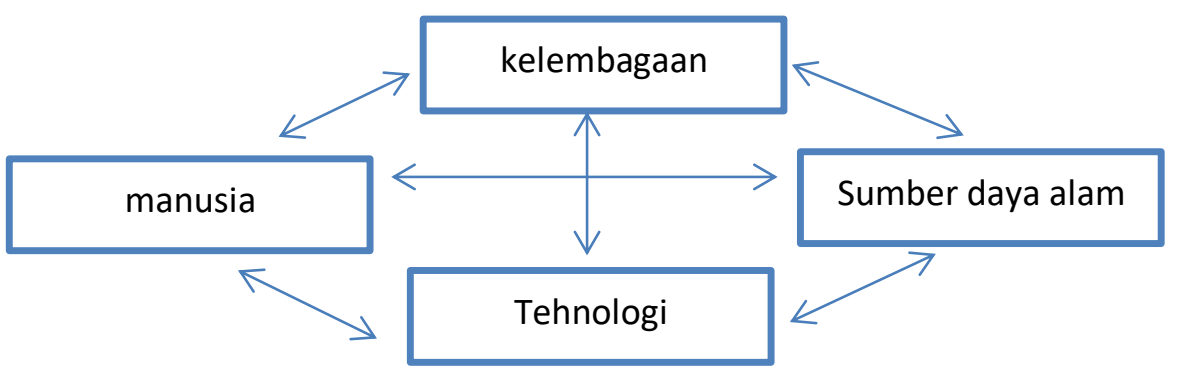


Akibat pengorganisasian Tehnologi untuk memanfaatkan alam, maka timbbullah hal-hal yang merusak dan menghancurkan lingkungan. Kelestarian lingkungan tidak mendapatkan perhatian yang memadai, interaksi sosial dan interaksi lingkungan diabaikan.

\section{Etika lingkungan Mutlak Dibutuhkan}

Guna mencegah kerusakan lingkungan yang tak terkendali, etika lingkungan mutlak dibutuhkan. Norma atau kaidah yang mengatur perilaku manusia dalam berhubungan dengan alam serta nilai dan prinsip moral yang menjiwai perilaku manusia dalam berhubungan dengan alam tersebut. Pengertian ini memberikan pemaparan bahwa makhluk non-manusia mendapatkan perhatian dalam etika. Lingkungan atau alam masuk sebagai bagian dari komunitas moral. Etika lingkungan merupakan kritik atas etika yang selama ini dianut oleh manusia yang pada komunitas sosial manusia. Etika lingkungan hidup menuntut agar etika dan moralitas tersebut diberlakukan juga bagi komunitas biotis atau komunitas ekologis. Etika ini juga dipahami sebagai refleksi kritis tentang apa yang harus dilakukan manusia dalam menghadapi pilihan-pilihan moral yang terkait dengan isu lingkungan hidup.

\section{Manusia Dicipta Untuk menjaga Alam}

Manusia dicipta adalah untuk menjaga dan bukan merusak alam. Itulah inti dari teologi penciptaan. Konsep tersebut penting untuk dimengerti sebagai mandat Ilahi. Karena itu, manusia mempunyai tanggung jawab terhadap kelestarian alam, manusia perlu menghargai dan merawat alam. Selanjutnya dalam cara pandang Kristen juga di yakini bahwa Tuhan adalah perancang dan pencipta terbaik, manusia diciptakan segambar dan serupa dengan Allah, manusia berkuasa atas alam.

Alkitab sebagai sumber nilai dan moral Kristen untuk menjadi pijakan dalam memandang dan mengapresiasikan alam. Alkitab sebenarnya mengajak manusia memberikan penghargaan yang tinggi terhadap ciptaan Allah lainnya, termasuk alam atau lingkungan hidup. Perhatikanlah kajian teologi kontekstual- ekologis berikut ini:

\section{Teologi Ciptaan}

Teologi ciptaan menekankan karya Allah yang memberikan hidup kepada seluruh ciptaan (Maz. 104). Dalam hal ini, manusia dilihat sebagai bagian integral dari alam bersama tumbuh-tumbuhan., hewan, dan ciptaan lainnya. Tanggung jawab manusia adalah bekerja untuk Tuhan dalam memelihara dan mengelola lingkungan hidup, bukan mendominasi apalagi mengeksploitasinya.

\section{Solidaritas dengan Alam}

Kesadaran bahwa seluruh ciptaan berharga di mata Tuhan, membawa kita untuk membangun sikap solidaritas dengan alam. Kita memperlakukan lingkungan hidup sebagai sesama ciptaan yang harus dikasihi. Dijaga, dipelihara, dan dipedulikan. Kita mencintai dan memperlakukan lingkungan hidup dengan sentuhan kasih sebagaimana sikap Tuhan, kita membangun solidaritas baru dengan alam yang telah rusak.

3. Spiritualitas Ekologis

Spiritualitas ini dibangun dengan dasar penghayatan iman bahwa semua ciptaan diselamatkan dan dibaharui oleh Tuhan. Pembaharuan itu menciptakan kehidupan yang harmonis. Spiritualitas ekologis mempunyai dasar pada pengalaman manusiawi yang berhadapan dengan kehancuran lingkungan hidup sekaligus berhadapan dengan pengalaman akan yang mahakudus, yang mengatasi segalanya. Dalam pengalaman ini, kita dipanggil untuk secara kreatif memelihara kualitas kehidupan, dipanggil untuk bersama Sang Penyelenggara hidup ikut serta mengusahakan shalom, kesejahteraan bersama dengan seluruh alam. Spiritualitas ekologis terwujud dalam macam-macam tindakan etis sebagai wujud tanggung jawab untuk ikut memelihara lingkungan hidup. Demikianlah dapat disampaikan bahwa baik manusia maupun segala ciptaan atau makhluk yang lain merupakan suatu kesatuan kosmik yang memiliki nilai yang berakar dan bermuara di dalam Kristus.

Sejauh ini misi gereja fokus pada hal jiwa-jiwa manusia atau kegiatan lain yang melayani manusia. Sudah saatnya gereja sebagai pembawa misi Allah harus menyadari bahwa gereja memiliki tugas panggilan menjaga keutuhan ciptaan atau kelestarian lingkungan hidup, misalnya dengan membuat program-program sebagai berikut;

1. Pembinaan tentang kesadaran Ekologis. Pembinaan ini merupakan upaya gereja untuk meningkatkan anggotanya bahwa alam adalah ciptaan Allah yang harus 
dihargai dengan memelihara dan melestarikannya. Misalnya dalam PA atau pembinaan khusus dan tema-tema kebaktian.

2. Perayaan lingkungan hidup dalam liturgi. Misalnya membuat ibadah khusus untuk merayakan hari lingkungan hidup. Dalam ibadah, ada baiknya kita melakukan penyesalan dosa yang dilakukan terhadap alam semesta karena ulah manusia yang telah merusak alam. Pentingnya juga untuk menciptakan dan menyanyikan lagu-lagu rohani yang bertemakan alam.

3. Menyadarkan terus tentang kerusakan lingkungan hidup yang berdampak langsung kepada manusia. Gereja perlu menyuarakan kritik atau memberikan masukanmasukan bagi masyarakat ataupun pemerintah terkait dengan upaya melestarikan lingkungan hidup.

4. Menata lingkungan gereja dengan memperhatikan keseimbangan Ekologis. Misalnya jangan habiskan tanah untuk mendirikan bangunan, tapi berikan ruang untuk tanaman-tanaman. Kita bisa membangun lingkungan gereja yang hijau dan asri.

5. Gerakan penanaman pohon bagi seluruh warga gereja.

6. Mengajak anggota jemaat membudayakan gaya hidup yang ramah dan dekat dengan alam. Misalnya dengan memisahkan sampah plastik, membuat lingkungan sekitar rumah menjadi hijau dengan tanam-tanaman. Menanam pohon di sekitar gereja.

7. Membangun kerja sama dengan lembaga atau kelompok pencinta alam. Misalnya organisasi WALHI (Wahana Lingkungan Hidup Indonesia) untuk memperjuangkan pembangunan yang berwawasan ekologis.

Berikut adalah gambar-gambar dari hasil sosialisasi penghijauan yang dilakukan jemaat GKSI IMMANUEL kecamatan Kuala Behe;
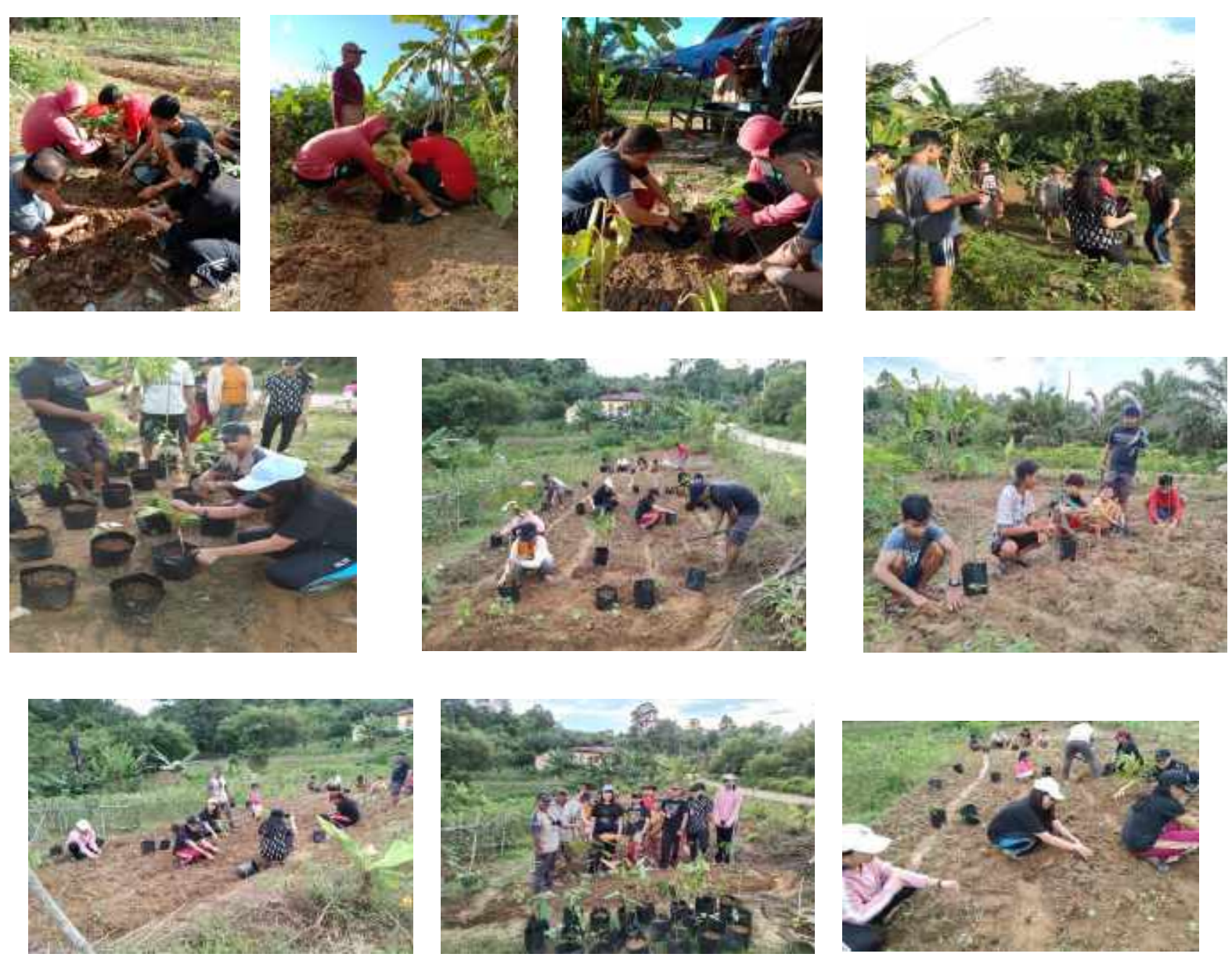

\section{KESIMPULAN}

Memperjuangkan kelestarian lingkungan hidup bukanlah hal yang mudah. Pada sisi yang lain, kekristenan perlu berpikir atau berteologi dengan menempatkan alam sebagai bagian integral dari karya penciptaan Allah. Konsep keselamatan perlu dilihat dengan kacamata yang lain, yakni secara holistik. Tidak ada keselamatan yang mengesampingkan kerusakan alam atau lingkungan. Menjadi Kristen, berarti menjadi bagian dari karya Allah untuk menata kehidupan yang harmonis. Keikutsertaan dalam melestarikan alam, bukan lagi harus dilakukan sebagai bentuk formalitas tata negara. Tetapi dilaksanakan sebagai 
bentuk kesadaran dan tanggung jawab umat kristen sebagai umat ciptaan Allah. Yang bisa di mulai dari menyadarkan diri sendiri, berkelanjut ke lingkungan sekitar dan lalu masyarakat luas. Semua itu tentu saja, diperbuat untuk memuliakan Allah Sang Pencipta.

\section{Daftar Pustaka}

Bauckham, Richard. The Bible and Ecology: Rediscovering the Community of Creation. Baylor University Press, 2010.

Brownlee, Malcolm. Tugas Manusia dalam Dunia Milik Tuhan, cet.4. Jakarta: BPK Gunung Mulia, 1997.

Borrong, Robert, P. Etika Bumi Baru. Jakarta: BPK Gunung Mulia, 1999.

Drummond, Celia Diane. Teologi dan Ekologi. Cet. 6. Jakarta: BPK Gunung Mulia, 2015.

Prediger, Steven Bouma, For the Beauty of the Earth: a Christianity vision for Creation Care, Cet.2. Grand Rapids, Baker Academic, 2010.

Salurante, Tony. "Teologi Misi dan Kepedulian terhadap Ciptaan: Menjangkau Misi Ekologi yang Terabaikan" dalam Menjangkau Yang Tidak Terjangkau: Bunga Rampai Pemikiran Teologis dalam Memperingati 1 Dekade Sttar. Ed. Adi Putra et.al. Jakarta. Views, 2018. 